\title{
Burgernomics: An Instructional Case On The Law Of One Price
}

Carolin E. Schmidt, Heilbronn University, Germany

\begin{abstract}
Jane just moved back to her hometown in Western New York to start a job at a bank. One evening, she meets her old friend Sally, who traveled the world for the past five months and tells Jane about her experiences with the different price levels in all the countries that she visited. Jane, being a recent graduate in international economics and finance, understands the underlying dynamics that are due to exchange rate theory and sheds light on the price discrepancies prevailing between the different currencies.

This case focuses on the construction of the Big Mac index and on conveying the theoretical basis of the index (Purchasing Power Parity and the Law of One Price) to undergraduate students in business and economics. It is appropriate for use in undergraduate courses such as international finance, financial markets or international economics. It could also be used in (international) marketing courses to show the importance of product pricing.
\end{abstract}

Keywords: Law of One Price; Purchasing Power Parity; Exchange Rate Theory; Big Mac Index

\section{LEARNING OBJECTIVES}

O ndergraduate students often struggle with the alleged irrelevance of economic theories for their future careers in the corporate world. Fortunately, in 1986, The Economist invented the Big Mac index to "make exchange-rate theory more digestible" (The Economist, 2015). This teaching case uses the Big Mac index to convey the Law of One Price and Purchasing Power Parity Theory to undergraduate business and economics students. Besides acquainting students with the computation of the Big Mac index and inquiring about its weaknesses, this case study also stimulates general economic thinking and analytical problem-solving skills. Students can either be asked to do the exercise using pen and paper or Excel.

\section{INTRODUCTION}

Jane's biggest passion has always been economics. What fascinates her most is the interplay between economic forces, businesses' financial decisions and consumer behavior. She recently graduated with a master's degree in international economics and finance and is going to take up a job as a consultant in the economics department of a large international banking group next month. Fortunately, this company has a subsidiary close to her hometown in Olean, NY, which is why she moved back just a couple days ago.

On her first day back home she ran into a friend whom she hadn't seen for a while. They decided to meet the following evening at a restaurant they frequently visited before their paths went separate ways five years ago. Sally majored in cultures and language studies and, as a reward for her graduation, decided to travel the world for 5 months. She visited some of the most beautiful places in the world, including Sri Lanka, Turkey, Switzerland, Venezuela, and Thailand, to mention but a few.

"I was shocked when I went to a restaurant in Zurich for the first time" said Sally before she took a big bite of her cheeseburger, and added, "I mean, the Swiss food was absolutely amazing; but it was so expensive. I would've never thought that you can actually spend $\$ 25$ on a Caesar salad. In comparison to that, the food in Venezuela was so ridiculously cheap that I gained 4 pounds in just three weeks. Isn't that crazy?" 
Jane watched her take another bite of her $\$ 8$ burger. She started to smile when she thought of her last international economics class. "Did you know that there is actually a relationship between burgers and economics?" Sally looked at her in surprise.

\section{PURCHASING POWER PARITY AND THE LAW OF ONE PRICE}

"Well, you know, it is quite easy. A famous economic theory claims that when you look at the same basket of goods in two different countries, say, in Switzerland and the US, the values of both baskets should theoretically be the same because we assume that in two complete markets the exchange rate will move toward an equilibrium rate that equalizes the value of both baskets of goods in the long run. That's known as the Law of One Price."

Sally asked, "So, basically what you are saying is that the value of a basket of goods should be the same in both countries?"

"Exactly," Jane replied. "The implied exchange rate between the burgers should be the same as the actual exchange rate. It all relies on the Purchasing Power Parity (PPP) theory. For example, consider two countries with different disposable income; say 1,000 currency units in country A (CUA) and 800 currency units in country B (CUB). Then the same basket of goods which has a price of CUA 100 in country A should cost only CUB 80 in country B. That is, in both countries you can buy exactly 10 baskets of goods. If the exchange rate between the two currencies is CUA $1=$ CUB 0.8 , then you can convert your money from one currency to the other and buy the same amount of goods there."

"I think I understand. If I own CUA 1,000 and convert them to CUB, I end up with CUA $1 \times 1,000=$ CUB $0.8 \times$ $1,000=$ CUB 800 and can buy the same basket of goods as in country A. But what the heck does that have to with burgers?" Sally inquired.

"Well, you know, in the 1980's, The Economist invented the so-called Big Mac index which is - surprise! - based on hamburger prices instead of prices for entire baskets of goods. All you have to do is figure out the prices of a Big Mac in different currencies. That's easy - I mean; you can buy Big Macs almost anywhere! Theoretically, all those prices should be the same as in the US after you converted them to dollars. From my last vacation in Mexico I remember that a burger cost only 3 bucks. All those theories would claim the Mexican peso to be undervalued by roughly 35 percent because a Big Mac in the US costs $\$ 4.79$. The index is quite popular by the way. They now publish it twice a year and there are a lot of studies about it. There is even a new word for it: burgernomics."

"Ha ha, that's funny. I bet they didn't expect it would become such hit! However, there is something that I don't understand yet. Assuming that a currency is at its correct level, could it still be that for someone from the US a burger from that country is expensive? I still have my Caesar salad experience in mind."

"Of course, it all depends on the purchasing power in a given country; and this involves expenses but also income. The higher the income, the higher are probably the prices. Suppose you live in the country with an income of only $\$ 800$ and want to buy a basket of goods from the $\$ 1,000$ income economy. You'd have to pay 20 percent more than in your home country although the basket is correctly valued. Also of course businesses are affected by this, since their clients and suppliers see themselves faced with a different purchasing power when they buy goods from a foreign country."

Meanwhile, Sally finished her burger. The Big Mac index and its implications for the "real world" have fully caught her attention. Eventually she has to admit that economics is not as bad as she always thought.

\section{AUTHOR BIOGRAPHY}

Carolin E. Schmidt holds a Bachelor in International Business Administration and a Master in Accounting and Finance. She is a research associate and lecturer at Heilbronn University in Heilbronn, Germany where she has taught undergraduate classes in financial management, international finance, European financial markets and corporate finance. Her research interests are in the areas of finance and economics as well as internationalization and teaching methods for higher education. Email: carolin.schmidt@hs-heilbronn.de 


\section{REFERENCES}

The Economist (2015). The Big Mac index, July 2015. Retrieved October 1, 2015 from http://www.economist.com/content/bigmac-index.

World Bank (2015). GDP per capita, PPP (current international \$). Retrieved October 2, 2015 from http://data.worldbank.org/indicator/NY.GDP.PCAP.PP.CD.

\section{QUESTIONS}

1. a. Help Sally and construct the Big Mac Index for the countries she visited during her world trip using the data reported in Table 1and the information presented in the case.

b. Which currencies are over and which are undervalued compared to the USD? By how much (in percent)?

c. Plot the results in a bar graph.

d. Compute the implied exchange rate between the US burgers and the burger in the 5 countries (Swiss franc (SFR), Sri Lankan rupee (LKR), Thai baht (BHT), Turkish lira (TRY) and Venezuelan bolivar (VEF) by equating the price of a burger in the US with the price of a burger in the foreign currency. Compare your results with the actual exchange rates reported in column (2) of Table 1.

2. What are the weaknesses and practical limitations of the Big Mac index?

3. What is the general problem with a burger denominated in euros?

4. What are potential opportunities for businesses trading goods in foreign currencies?

5. Suppose you buy and sell Big Macs in different currencies. How does this influence the exchange rate?

Table 1. Raw data for the Big Mac index as of July 2015

\begin{tabular}{l|c|c}
\hline \multicolumn{1}{c|}{ Country } & $(1)$ & (2) \\
\hline Sri Lanka & Burger price in local currency (LC) & Exchange rate (LC/USD) \\
\hline Switzerland & 350 & 133.85 \\
\hline Thailand & 6.5 & 0.95 \\
\hline Turkey & 108 & 34.09 \\
\hline Venezuela & 10.25 & 2.65 \\
\hline United States & 132 & 197 \\
\hline
\end{tabular}

Source: The Economist (July 2015), http://www.economist.com/content/big-mac-index 
Figure 1. World map showing the currency misalignments according to the Big Mac Index

\section{The Big Mac index}

\begin{tabular}{l|l|l|l}
\cline { 2 - 3 } Select base currency: & US dollar $\nabla$ & Raw index & Adjusted index
\end{tabular}

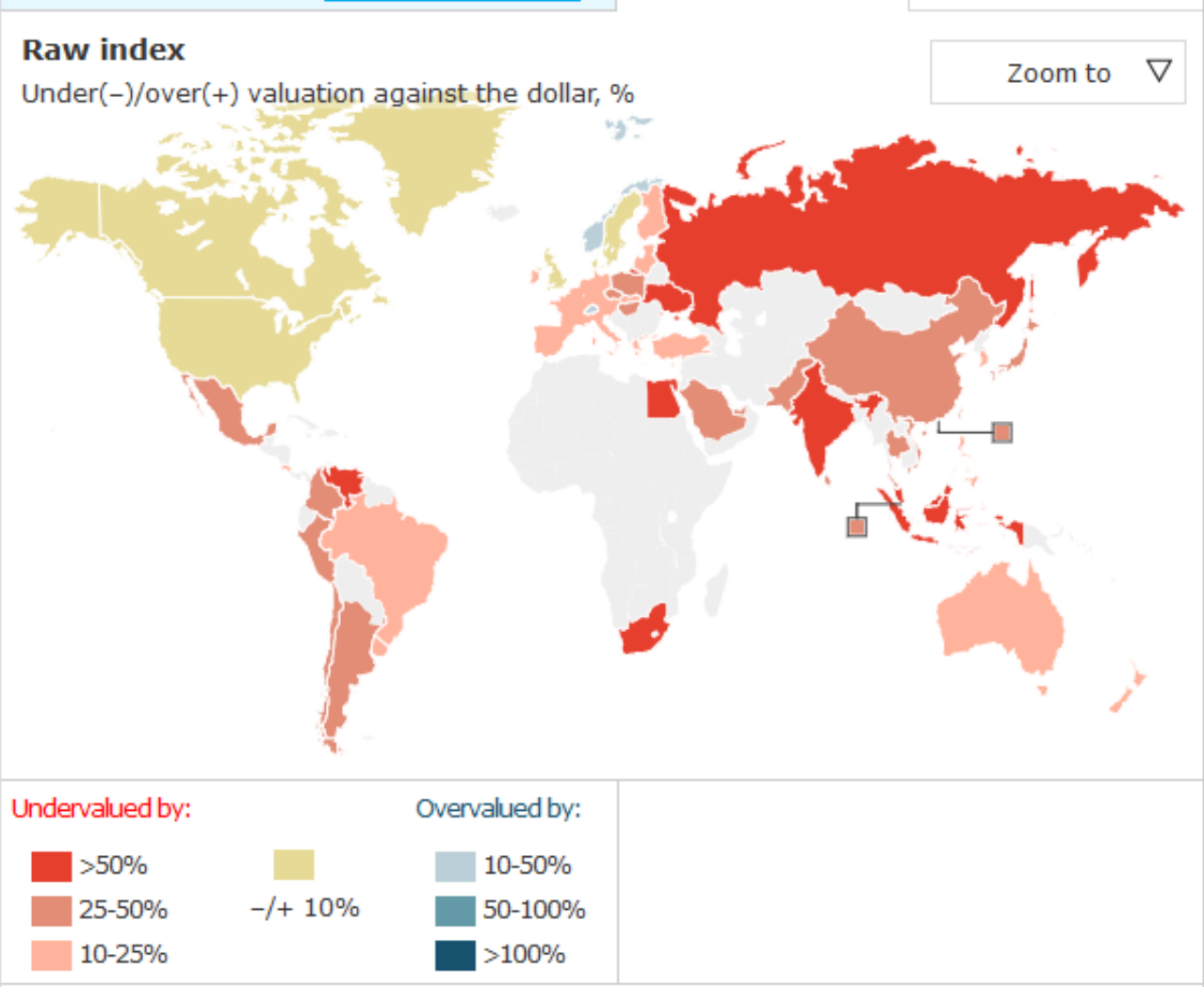

Source: The Economist (July 2015), http://www.economist.com/content/big-mac-index 


\section{TEACHING NOTES}

\section{Answers to Questions}

1.

a. or the construction of the Big Mac index, the burger prices first have to be converted to US dollars using the exchange rates given in Table 1:

$$
\begin{aligned}
& \text { PSRI }=350 / 133.85=\$ 2.61 \\
& \text { PSWI }=6.5 / 0.95=\$ 6.82 \\
& \text { PTHAI }=108 / 34.09=\$ 3.17 \\
& \text { PTUR }=10.25 / 2.65=\$ 3.87 \\
& \text { PVEN }=132 / 197=\$ 0.67
\end{aligned}
$$

This is how much a burger in a specific country should cost in US dollars. According to the table, the price of a Big Mac in the US is \$4.79.

b. $\quad$ VSRI $=2.61 / 4.79-1=-0.4541$ (currency undervalued by 45.41 percent)

VSWI $=6.82 / 4.79-1=0.4242$ (currency overvalued by 42.42 percent)

VTHAI $=3.17 / 4.79-1=-0.3385$ (currency undervalued by 33.85 percent)

VTUR $=3.87 / 4.79-1=-0.1912$ (currency undervalued 19.12 percent)

$\mathrm{VVEN}=0.67 / 4.79-1=-0.8601$ (currency undervalued by 86.01 percent)

c.

Figure 2. The Big Mac index for Switzerland, Turkey, Thailand, Sri Lanka and Venezuela

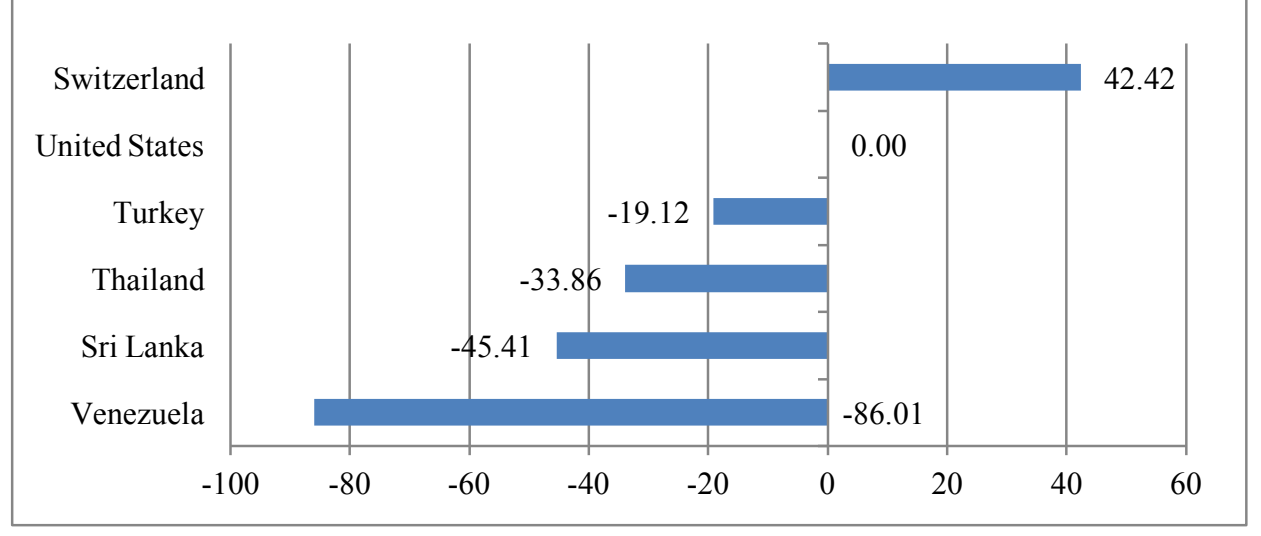

d. Implied exchange rate between Sri Lankan rupee and US dollar:

LKR $350=1$ burger $=\$ 4.79 \rightarrow \$ 1=\operatorname{LKR} 350 / 4.79=\operatorname{LKR} 73.07$

Implied exchange rate between Swiss franc and US dollar:

SFR $6.5=1$ burger $=\$ 4.79 \rightarrow \$ 1=$ SFR $6.5 / 4.79=$ SFR 1.36

Implied exchange rate between Thai baht and US dollar:

THB $108=1$ burger $=\$ 4.79 \rightarrow \$ 1=$ THB $108 / 4.79=$ THB 22.55

Implied exchange rate between Turkish lira and US dollar:

TRY $10.25=1$ burger $=\$ 4.79 \rightarrow \$ 1=$ TRY $10.25 / 4.79=$ TRY 2.14

Implied exchange rate between Venezuelan bolivar and US dollar:

VEF $132=1$ burger $=\$ 4.79 \rightarrow \$ 1=\operatorname{VEF} 132 / 4.79=\operatorname{VEF} 27.56$ 
2.

- The assumption of a complete market is questionable.

- The Law of One Price requires that the good be homogenous. The Big Mac almost fulfills this requirement (except for slight differences in the recipe, e.g., in India the burgers come with chicken patties); however, due to different cost of material, local wages, cost of lease, tariffs and other trade barriers, the production cost is not the same.

- Different commercial strategies could lead to different prices in different places, e.g. a standard Big Mac could be sold relatively cheap while a chicken burger could be relatively expensive. Also, within a given country, burger prices may vary.

- One would assume that in richer countries burgers cost more and vice versa. This is not reflected in the standard version of the Big Mac index, which relies on pure equilibrium theory.

To address some of the above criticisms, The Economist added an adjusted version of the index since in richer countries goods tend to be more expensive than in poorer countries. For more information on the adjusted index see www.economist.com/content/big-mac-index

3. The euro is the single currency of currently 19 member states of the European union. Although they have the same currency, their economies are very different from each other. That is, e.g., the gross domestic products, production costs, wages, etc., vary a lot between the countries. Therefore, it makes more sense to calculate the Big Mac Index for every country in the Eurozone separately. This can be done to measure the degree of financial integration in the euro area.

4. Businesses can make profits with goods bought in an undervalued currency. For example, suppose a car manufacturer buys steel from Russia at a price of 9,000 Russian rubles per ton, and that the ruble is undervalued. Since the company has to exchange US dollars to (cheap) rubles in order to buy (cheap) steel from the Russian company, the demand for rubles increases which raises the exchange rate. Remember that exchange rates fluctuate in order to equalize differences in the price levels of two different countries. Buying steel in an undervalued currency makes the cost of producing a car less expensive. It is comparable to buying a cheap burger n Venezuela and selling it at a "normal" price in the US.

Another possibility for making profits is buying (usually nonperishable) goods in an undervalued currency and selling them in an overvalued currency at the same time (buy cheap, sell high). Using the unrealistic example of the Big Mac index, a company would buy a cheap burger in Venezuela (\$0.67) and sell it expensive in Switzerland (\$6.82).

Of course, the converse argument works as well, i.e., businesses can make losses buying in an overvalued currency and selling in an undervalued currency.

5. Buying burgers from a country with an undervalued currency (e.g., Venezuela) and selling it in a country with an overvalued currency (e.g., Switzerland) would push prices up in Venezuela and down in Switzerland, and the exchange rate would move towards an equilibrium value.

\section{ADDITIONAL RESOURCES}

1. The Economist publishes a handful of interactive graphs at http://www.economist.com/content/big-mac-index and offers the raw data and the Big Mac index for 48 countries plus the euro area in spreadsheet format for free (January and July of every year).

2. Usually, I ask my students to create their own index (e.g., a GTA 5 index, an iPad mini index or the like). For this group assignment, they decide on a product and search its price in different countries. Taking the current exchange rate, they convert the prices to their home currency (this makes it interesting for everybody since we have many international students) and plot the results in an appropriate graph. I have made the experience that students like this task very much and they try to outdo their fellow students by constructing the most creative index of their class. 